\title{
TELAAH SIGNIFIKANSI KONSEP MANUSIA MENURUT AL-GHAZÂLÎ
}

\author{
M. Yasir Nasution \\ Fakultas Syariah IAIN Sumatera Utara \\ Jl. Willem Iskandar Pasar V Medan Estate, Medan 20371 \\ e-mail: nasution_my@yahoo.com
}

\begin{abstract}
Abstrak: Al-Ghazâlî lahir pada masa kejayaan pemikiran rasional Islam klasik abad ke-10. Setelah melakukan serangkaian petualangan intelektual-yang pada titik tertentu membawanya ke titik krisis mental-ia menjadi salah seorang pemikir multi disiplin yang berpengaruh sangat luas. Artikel ini berargumentasi bahwa pemikirannya tentang spiritualisme memiliki potensi besar untuk menjawab berbagai pertanyaan yang menghantui kehidupan manusia modern. Lebih khusus, penulis berpendapat bahwa manusia modern sangat membutuhkan teori al-Ghazâlî yang memadukan indera, akal, dan intuisi sebagai sumber pengetahuan yang absah. Teori ini dapat menyediakan dasar epistemologi yang kokoh sekaligus satu cara yang berimbang dalam melihat hidup manusia.
\end{abstract}

\begin{abstract}
An Analysis of the Significance of al-Ghazâlî's Concept of Men. Born at the heyday of Islamic classical rationalism of the tent century, and after going through series of intellectual adventures that at points bring him to mental breakdown, al-Ghazâlî established himself as an Islamic polymath of towering influence. The present article argues that his thought on spiritualism is of great potential in answering the many questions faced by modern man. More specifically, our present author is of the opinion that modern man is in dear need of al-Ghazâlî's theory of integrating senses, reason, and intuition as equally legitimate sources of knowledge. This theory could provide not only a sound epistemological basis but also a balanced way of perceiving human life.
\end{abstract}

Kata Kunci: Al-Ghazâlî, spiritualitas, epistemologi, manusia, tasawuf

\section{Pendahuluan}

Al-Ghazâlî (1058-1111 M) secara populis lebih dikenal melalui buku-bukunya yang bercorak tasawuf ${ }^{1}$ dan untuk tingkatan tertentu popularitasnya menonjol karena kritiknya

${ }^{1}$ Bukunya yang lebih banyak dibaca di pesantren-pesantren adalah Ihya' 'Ulûm al-Dîn dan 
terhadap sejumlah proposisi-proposisi metafisik para filosof Muslim, ${ }^{2}$ seperti Ibn Sînâ dan al-Fârâbî. Di samping itu, ia juga dipandang sebagai pelanjut teologi Asy'arî. ${ }^{3}$ Sebab itu, al-Ghazâlî dalam gambaran masyarakat pada umumnya adalah seorang figur sufi yang anti filsafat dan penjaga paham teologi yang bercorak fatalistik. Berpijak pada gambaran seperti inilah, tampaknya, al-Ghazâlî dituduh sebagai biang kemunduran umat Islam pada zaman sesudahnya; setidak-tidaknya dianggap memengaruhi kesadaran umat yang menyebabkannya terbelakang. ${ }^{4}$

Tuduhan itu memang bukan tanpa alasan. Tasawuf mempunyai potensi membuat orang meninggalkan dunia karena asyik dengan Tuhan. Kritiknya yang keras terhadap sejumlah pemikiran filosof dapat menyebabkan orang takut berfilsafat; dan teologi Asy'arî yang sudah mulai bersifat dinamis di tangan al-Baqillânî dan al-Juwainî kembali bersifat fatalistik pada buku-buku teologi al-Ghazâlî. Di samping itu, al-Ghazâlî, didukung oleh faktorfaktor historis "terlanjur" menjadi besar. Ia dipandang sebagai "benteng" Islam (hujujat alIslâm), ${ }^{5}$ yang menyelamatkannya dari pengaruh unsur-unsur pemikiran luar yang dapat merusak. Ia bahkan pernah disebut sebagai Muslim terbesar sesudah Nabi Muhammad. ${ }^{6}$ Kharisma al-Ghazâlî yang demikian besar dihubungkan dengan gambaran kesufian, anti filsafat, dan teologi fatalistiknya, dapat merupakan alasan yang kuat untuk menujukan tuduhan tersebut kepadanya.

Meskipun demikian, agaknya, kurang tepat apabila segi-segi tertentu dari pemikirannya yang diasumsikan memengaruhi umat dijadikan dasar untuk menilainya sebagai penyebab kemunduran umat. Dengan cara seperti itu, seseorang dapat terjerumus ke dalam kesadaran a historis memahami figur-figur sejarah dan pemikiran-pemikiran mereka. Dengan cara itu, seseorang seperti mencabut al-Ghazâlî dari konteks zamannya atau memandang pikiranpikirannya sebagai akhir dari proses pemikiran yang berkembang, yang harus diikuti.

Cara yang lebih tepat barangkali adalah meletakkan pikiran-pikirannya pada arus pemikiran zamannya untuk seterusnya merekonstruksi pikiran-pikirannya itu menjadi satu sistem dan mencari bagian paling substansial yang dianggap mendasari atau sekurangkurangnya memengaruhi keseluruhan pemikirannya. Dengan cara demikian lebih mudah dilihat signifikansi pemikirannya pada zaman yang senantiasa berubah. Tulisan ini tidak akan mengadakan rekonstruksi pemikiran al-Ghazâlî, tetapi membatasi diri pada usaha melihat signifikansi konsep manusianya dalam dunia modern. Sebab, konsep manusia

Minhaj al-Ẩbidîn, termasuk syarah Ihya' 'Ulûm al-Dîn, yaitu Ithaf al-Sadat al-Muttaqîn oleh alZubaidî, yang corak tasawufnya sangat menonjol.

${ }^{2} \mathrm{Hal}$ ini dilakukannya terutama melalui buku Tahafut al-Falâsifah.

${ }^{3}$ Bukunya yang lebih populer dalam hal ini adalah al-Iqtishâd fì al-I'tiqâd.

${ }^{4}$ Di Indonesia, tokoh yang secara terus terang menyatakan tuduhan ini adalah Sutan Takdir Ali Syahbana.

${ }^{5}$ Nurcholish Madjid, Khazanah Intelektual Islam (Jakarta: Bulan Bintang, 1984), h. 34.

${ }^{6}$ William Montgomery Watt, The Faith and Practice of al-Ghazâlî (London: George Allen and Unwin Ltd., 1953), h. 14. 
dianggap sebagai bagian paling substansial dari sistem pemikiran seseorang. Menurut Ernst Cassirer, ia adalah pusat yang tetap dan tidak tergeser dari semua pemikiran filosofis. ${ }^{7}$ Sebab itu, segala persoalan yang dihadapi umat manusia selalu dapat dirujuk inti permasalahannya pada konsep tentang manusia.

Ditemukan dua aspek pemikiran al-Ghazâlî tentang konsep manusia yang berkaitan dengan persoalan manusia modern, yaitu aspek epistemologi dan aspek orientasi hidup. Kedua aspek ini mengandung muatan spiritualitas yang jelas, yang mungkin dapat memberi sumbangan bagi perkembangan epistemologi dan pemenuhan diri manusia modern.

Abad modern adalah zaman ketika manusia menemukan dirinya sebagai kekuatan yang dapat menyelesaikan persoalan-persoalan hidupnya. Penemuan metode ilmiah yang berwatak empiris dan rasional $^{8}$ secara menakjubkan membawa kemajuan ilmu pengetahuan dan teknologi yang luar biasa. Industri dan berbagai macam penemuan ilmu pengetahuan membawa kemudahan-kemudahan hidup, membuka wawasan kehidupan baru, dan melahirkan pola pemikiran baru, yang disebut modernisme. Modernisme ditandai dengan rasionalisme, kemajuan, dan sekularisme. ${ }^{9}$ Bersamaan dengan itu, pengetahuan yang tidak didasarkan pada ukuran-ukuran ilmiah dan nilai-nilai religius tidak mendapatkan apresiasi yang memadai.

Modernisme akhirnya dirasakan membawa kehampaan dan ketidakbermaknaan. ${ }^{10}$ Timbul berbagai kritik dan usaha pencarian baru. Manusia membutuhkan pola pemikiran baru yang diharapan membawa kesadaran dan pola kehidupan baru. Kritik terhadap modernisme dan usaha pencarian ini sering disebut pascamodernisme atau neomodernisme. Fenomena spiritualitas tampak muncul pada pascamodernisme. Dari sudut pemunculan spiritualisme inilah terbuka jalan yang mudah melihat signifikansi konsep manusia al-Ghazâlî. Seperti dikemukakan di atas, signifikansi itu dihubungkan dengan dua aspek penting konsep manusia, yaitu aspek epistemologi dan aspek orientasi hidup.

\section{Epistemologi al-Ghazâlî}

Al-Ghazâlî lahir pada tahun 450 H./1058 M. di Thus, salah satu kota di Khurasan yang penduduknya sangat heterogen, baik dari segi paham keagamaan maupun dari segi suku bangsa. ${ }^{11}$ Hidup di lingkungan keluarga agamis dan miskin, tetapi dengan kesungguhannya ia dapat mempelajari bermacam-macam ilmu yang berkembang pada masanya.

${ }^{7}$ Ernst Cassirer, Manusia dan Kebudayaan, terj. Alois A. Nugroho (Jakarta: Gramedia, 1987), h. 3.

${ }^{8}$ Jujun S. Suriasumantri, Ilmu dalam Perspektif (Jakarta: Gramedia, 1983), h. 10.

${ }^{9}$ Akbar S. Ahmed, Postmodernism and Islam (London-New York: Routledge, 1992), h. 29.

${ }^{10}$ Hanna Djumhana Bastaman, "Dimensi 'Spiritualitas' dalam Teori Psikologi," dalam Ulumul Qur'an, Nomor 4, Vol. V, Tahun 1994, h. 16.

${ }^{11}$ Al-Subkî, Thabaqat al-Syafi'iyah al-Kubrâ, Juz IV (Mesir: Mushthafa al-Bâbî al-Halâbî, t.t.), h. 102. 
Ia belajar fiqih dan ilmu-ilmu dasar yang lain pada Ahmad al-Radzkanî di Thus dan pada al-Ismấilî di Jurjan. Pada tahun 473 H., ia pergi ke Naisabur untuk belajar di madrasah al-Nizhamiyah, dan mempelajari ilmu kalam dan logika dari al-Juwainî. ${ }^{12}$

Apabila diperhatikan, bidang-bidang ilmu yang diperolehnya sampai meninggalnya al-Juwainî tahun $478 \mathrm{H}$, terdiri atas bidang-bidang yang secara metodologis berbeda. Ilmu fiqih dan ushul fiqih adalah ilmu-ilmu yang dirancang untuk kepentingan pelaksanaan ajaran-ajaran Islam secara formal, dan pendekatannya, jelas, sangat formalistis. Ilmu kalam bertujuan untuk menanamkan dasar-dasar akidah dan sekaligus mempertahankannya. Pendekatannya, meskipun senantiasa menggunakan Kitab Suci dan Hadis sebagai rujukan, adalah bersifat rasional. Artinya, akal-lah pada praktiknya yang menjadi kriteria kebenaran dalam memahami makna ayat-ayat Kitab Suci dan Hadis tersebut dalam banyak hal. Selain ilmu kalam, ia juga belajar logika, yang tidak diragukan lagi rasionalitasnya. Apabila cerita yang dikutip oleh Sulaimân Dunia dari Zwemer bahwa al-Ghazâlî telah belajar tasawuf sebelumnya dari Yûsuf al-Nassaj, ${ }^{13}$ adalah benar, maka sampai di sini alGhazâlî sudah mempelajari setidak-tidaknya tiga sistem pemahaman keagamaan yang tidak saja berbeda, tetapi juga secara metodologis bertentangan, yaitu yang formalistis, yang rasional dan yang intuitif.

Selanjutnya, setelah Nizham al-Mulk mengangkatnya menjadi tenaga pengajar di madrasah al-Nizhamiyah Baghdad pada tahun 484H., al-Ghazâlî memperdalam pengetahuannya tentang filsafat yang sedikit banyaknya telah diperolehnya dari al-Juwainî. ${ }^{14}$

Setelah mempelajari ilmu-ilmu 'aqliyat, al-Ghazâlî mempunyai kecenderungan yang sangat rasional. Dalam buku-buku yang ditulisnya sebelum ia mengasingkan diri dengan cara hidup sufi antara tahun $488 \mathrm{H}$ dan $499 \mathrm{H}$., kecenderungan itu sangat terasa. Di dalam Mi 'yar al-'Ilm yang diperkirakan ditulisnya sebelum tahun 488 H., ia menegaskan bahwa tujuan buku itu, yang isinya sebenarnya adalah logika, adalah antara lain untuk memberitahu cara berpikir dan menalar. ${ }^{15}$ Ini menunjukkan kecenderungannya yang khusus terhadap logika. Di dalam al-Iqtishâd fi al-I'tiqad, ia memperlihatkan ketergantungan syara' terhadap akal. Ada proposisi-proposisi yang keberadaan syara' tergantung kepadanya, yaitu proposisi yang hanya diperoleh dengan akal, seperti adanya Tuhan. ${ }^{16}$

Penempatan kedudukan akal yang tinggi ini kemudian mengalami kegoncangan. Al-Ghazâlî mengalami kesangsian (al-syak). Kelihatannya, kesangsian al-Ghazâlî berpangkal dari keragaman pengetahuan yang dimilikinya yang masing-masing mempunyai ukuran

${ }^{12 ‘} \mathrm{Abd}$ al-Raḩman Badâwî, Muallafat al-Ghazâlî (Damaskus: al-Majlis al-A’la li Ri‘âyat alFunûn, 1961), h. 4-5.

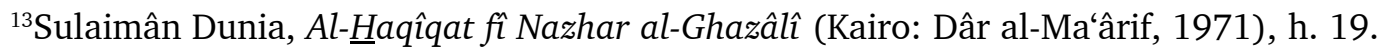

${ }^{14}$ Ahmad Fu'ad al-Ahwanî, dalam 'Abd al-Karîm 'Utsman, Sîrah al-Ghazâlî (Damaskus: Dâr al-Fikr, t.t.), h. 19.

${ }^{15}$ Al-Ghazâlî, Mi'yar al-'Ilm (Kairo: Dâr al-Ma'ârif, 1960), h. 59.

${ }^{16}$ Al-Ghazâlî, Al-Iqtishâd fí al-I'tiqâd (Kairo: Muhammad 'Alî Shubaih, 1962), h. 107. 
kebenaran sendiri. Menurutnya, kebenaran itu adalah satu, sumbernya adalah al-fithrah al-ashliyah. Sebab, berdasarkan hadis Nabi, setiap anak dilahirkan atas fitrahnya, yang membuat anak itu menjadi Yahudi, Nasrani atau Majusi adalah kedua orang tuanya. ${ }^{17}$ Artinya, pengetahuan yang diajarkan orang tua atau guru itu adalah sesuatu yang datang kemudian dan menyebabkan keragaman dan pertentangan. Pengetahuan yang diperoleh melalui taklid yang didasari oleh talqin mengandung pertentangan dan perbedaan-perbedaan. Karena itu, ia merasa perlu mencari hakikat fithrah ashliyah dan membedakannya dari akidah-akidah yang datang kemudian serta memisahkan yang benar dari yang salah dalam pengetahuan-pengetahuan yang diperoleh secara taqlid itu. Dalam kenyataannya, membedakan yang salah dari yang benar, orang-orang juga berbeda pendapat. Karena itu, ia merasa perlu mengetahui hakikat segala sesuatu. Segala sesuatu, dilihat dari satu segi, adalah fakta objektif; tetapi dari sudut manusia, segala sesuatu merupakan ide-ide pada diri subjek (pengetahuan). Sebab itu, al-Ghazâlî menyimpulkan bahwa ia harus mulai dari hakikat pengetahuan. Sesuai dengan titik tolaknya semula, yaitu kebenaran, maka pengetahuan yang dicarinya adalah pengetahuan yang diyakininya benar (al-'ilm al-yaqîn). Tingkat kebenarannya tidak mengandung keraguan atau kemungkinan tersalah sama sekali, seperti kebenaran pengetahuan sepuluh lebih banyak daripada tiga. Tingkat kebenaran seperti itulah, selanjutnya, dicobanya untuk menjadi ukuran pengetahuanpengetahuan yang dimilikinya. ${ }^{18}$

Setelah memperhatikan pengetahuan-pengetahuan yang dimilikinya, al-Ghazâlî merasa bahwa pengetahuan-pengetahuan itu tidak mencapai tingkat kebenaran dan keyakinan seperti di atas, kecuali (mungkin) yang tergolong al-hissiyat (yang diperoleh melalui indera) dan al-dharuriyyat (yang sifatnya a priori dan aksiomatis). ${ }^{19}$ Sebab, kedua jenis pengetahuan ini tidak berasal dari orang lain, tetapi berasal dari diri subjek sendiri (al-Ghazâlî).

Ketika menguji pengetahuan inderawi, al-Ghazâlî melihat bahwa pengetahuan itu tidak terlepas dari kemungkinan tersalah. Akal, ternyata dapat membuktikan kesalahankesalahan inderawi. Bayang-bayang benda yang dalam pandangan mata, diam, ternyata dengan pengamatan dan eksperimen, akal menyimpulkan bahwa bayang-bayang itu bergerak. ${ }^{20}$ Dengan demikian, kepercayaannya kepada pengetahuan inderawi hilang. Kepercayaan selanjutnya tertumpu pada pengetahuan yang diperoleh melalui akal, seperti pengetahuan aksiomatis yang sifatnya a priori, sebab, akal telah berhasil memperlihatkan kelemahan indera.

Kepercayaan terhadap akal goncang kembali ketika ia memikirkan apa dasar yang membuat akal dipercaya. Kalau ada dasar yang membuat akal dipercaya, maka dasar itulah sesungguhnya yang lebih dipercaya, sebagaimana halnya akal menjadi dasar kepercayaan

\footnotetext{
${ }^{17}$ Al-Ghazâlî, Al-Munqidz min al-Dhalâl (Kairo: Silsilat al-Tsaqafat al-Islâmiyah, 1961), h. 7.

${ }^{18}$ Ibid.

${ }^{19}$ Ibid.

${ }^{20}$ Ibid.
} 
terhadap indera. Ketidakjelasan adanya dasar yang lebih tinggi daripada akal tidak mesti menunjukkan kemustahilannya. ${ }^{21}$ Dasar itu, semestinya, ada, sebab, kalau tidak ada, maka tidak ada alasan untuk mempercayai akal. Kalau akal tidak dipercaya, segala penge-tahuan tidak dapat dipercaya lagi. Kelihatannya, ada alasan lain yang membuat kepercayaannya kepada akal goncang. Ia melihat bahwa aliran-aliran yang menggunakan akal sebagai sumber pengetahuannya, ternyata, menghasilkan pandangan-pandangan yang bertentangan, yang sulit diselesaikan dengan akal. Akal pada dirinya seperti membenarkan pandanganpandangan yang bertentangan itu. Dengan akal saja takafu' al-adillat (antinomi) bisa terjadi. ${ }^{22}$ Seperti disebut di atas, yang dicarinya adalah al-ilm al-yaqîn yang tidak mengandung pertentangan pada dirinya. Pada akal ia tidak menemukannya.

Kemungkinan adanya sumber pengetahuan suprarasional itu diperkuatnya dengan adanya pengakuan para sufi bahwa pada situasi-situasi ( $a \underline{h} w a l)$ tertentu, mereka melihat hal-hal yang tidak sesuai dengan ukuran-ukuran akal, dan dengan hadis yang menyatakan bahwa manusia sadar (intabahu) dari tidurnya sesudah mereka mati. ${ }^{23}$ Berdasarkan pengakuan para sufi dan hadis ini, ada situasi di luar situasi normal, yang kesadaran manusia lebih tajam padanya. Dengan mengemukakan pengakuan para sufi dan hadis tersebut, ia berhadapan dengan dua kemungkinan tentang ada atau tidaknya sumber pengetahuan yang lain itu di dunia ini. Kalau benar pengakuan para sufi, maka sumber pengetahuan suprarasional iu terdapat di dunia ini; tetapi kalau tidak, sumber pengetahuan itu diperoleh hanyalah sesudah mati. Di sinilah al-Ghazâlî mengalami puncak kesangsiannya. Ia tidak mempunyai sumber pengetahuan yang dapat dipercayainya lagi untuk menemukan jalan keluar, sebab, ia telah menyangsikan segalanya, taqlid, indera dan akal.

Menurut pengakuannya, hampir dua bulan ia mengalami kekacauan psikologis tanpa kemampuan menyelesaikannya. ${ }^{24}$ Hanya dengan cahaya (nûr) yang diberikan Tuhan dengan tiba-tiba ke dalam hatinya, ia merasa sehat dan dapat menerima kebenaran pengetahuan yang a priori yang bersifat aksiomatis itu kembali. Kebenaran pengetahuan itu tidak diperolehnya melalui argumentasi yang terurai (al-adillat al-muharrarat), tetapi melalui nûr yang disebutnya sebagai kunci ma'rifat, dan merupakan makna dari al-syarah yang terdapat dalam ayat 125 surat al-An'âm. ${ }^{25}$

Hal yang ingin dikemukakannya dengan menceritakan proses kesangsian ini adalah bahwa al-dzauq (intuisi) lebih tinggi dan lebih dipercaya daripada akal untuk menangkap pengetahuan yang betul-betul diyakini kebenarannya. Pengetahuan yang lebih tinggi kebenarannya adalah yang diperoleh melalui nûr yang dilimpahkan Tuhan ke dalam hati manusia.

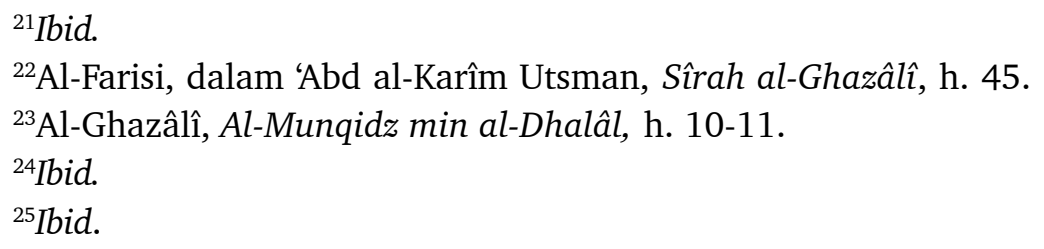


Sumber pengetahuan tertinggi itu disebutnya juga al-nubuwwat, yang pada nabinabi berbentuk wahyu dan pada manusia biasa berbentuk ilham. Ia menegaskan bahwa al-nubuwwat tidak dapat dimengerti dan dibuktikan dengan akal. Ia berusaha mendekatkan pengertian al-nubuwwat dengan jalan memperlihatkan kasus-kasus yang menunjukkan bahwa manusia dapat memperoleh pengetahuan langsung tanpa memperoleh bantuan indera dan argumen 'aqli. Hakikat al-nubuwwat tidak dapat digambarkan, sebab, ia hanya dapat dimengerti melalui pengalaman langsung. ${ }^{26}$

Dalam buku-bukunya yang ditulis sesudah ia memasuki kehidupan sufi, indera dan akal tidak dikesampingkan sama sekali kedudukannya sebagai sumber-sumber pengetahuan, tetapi diletakkan di bawah al-nubuwwat. Urutan sumber-sumber pengetahuan, dengan demikian, berdasarkan tingkat kepercayaan kepadanya adalah al-nubuwwat (wahyu pada nabi-nabi, ilham pada wali-wali), akal, dan indera.

Setelah menemukan ketenangan psikologis dan merasa ada sumber pengetahuan di atas akal, yaitu nûr yang dilimpahkan Tuhan secara langsung ke dalam hatinya, ia mulai memperhatikan aliran-aliran yang populer pada masanya, berdasarkan kategorisasi yang dilakukannya seperti disebut di atas, yaitu mutakallimun, para filosof, bathiniyah, dan para sufi. Menurutnya, kebenaran tidak mungkin keluar dari salah satu yang empat ini. ${ }^{27}$

Ilmu Kalam, menurutnya, dimaksudkan untuk mempertahankan akidah ahl al-sunnah dari gangguan ahl al-bid'ah. Dalam beberapa hal ilmu kalam berusaha mencari hakikat itu, tetapi karena keterbatasannya maka hasilnya tidak sempurna dan tidak dapat menyelesaikan perbedaan yang membingungkan itu. ${ }^{28}$ Karena itu, ia tidak puas dengan ilmu kalam.

Para filosof, menurutnya, berdasarkan pandangan mereka terhadap Tuhan, terdiri atas tiga golongan, yaitu materialis (al-dahriyun), naturalis (al-thabi'iyûn), dan teis (al-ilâhiyûn). ${ }^{29}$

Yang secara khusus dibahasnya dan dikritiknya adalah golongan ketiga dari para filosof, yaitu al-ilâhiyûn. Sebab, yang berkembang di dunia Islam pada umumnya, menurutnya, adalah ajaran-ajaran dari golongan ini melalui filosof-filosof Islam seperti Ibn Sînâ (w. 1037 M) dan al-Fârâbî (w. 950 M). Bidang pengetahuan mereka secara garis besar terdiri atas enam bidang, yaitu matematika, logika, fisika, politik, etika, dan metafisika. Ia menilai keseluruhan bidang pengetahuan para filosof dikelompokkan kepada tiga kategori, yaitu kufr, bid'ah, dan yang tidak harus diingkari. ${ }^{30}$ Kategori terakhir ini terdiri atas matematika, logika, fisika, politik, dan etika; sedangkan yang termasuk ke dalam dua kategori pertama pada umumnya adalah metafisika. Jelasnya, yang menyebabkan kufr itu adalah pandangan mereka dalam bidang metafisika, yaitu bahwa yang diberi ganjaran di akhirat adalah jiwa

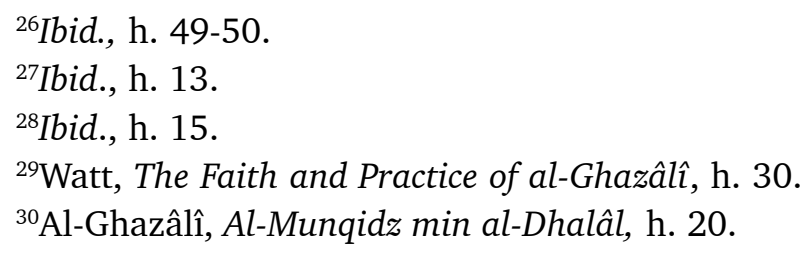


manusia saja; bahwa Tuhan hanya mengetahui universal; dan bahwa alam ini bersifat qadim. ${ }^{31}$ Menjadikan filsafat sebagai jalan mengetahui kebenaran metafisik tidak dapat diterimanya, karena hal itu membawa banyak pertentangan.

Keterangan dan penilaiannya yang disebutkan di atas adalah terhadap pengetahuanpengetahuan tertentu yang terdapat di kalangan filosof, bukan terhadap filsafat sebagai cara untuk menemukan kebenaran (pengetahuan).

Terhadap bathiniyah, kritiknya yang paling pokok adalah mengenai otoritas imam yang ma'shum sebagai sumber kebenaran. Al-Ghazâlî sependapat dengan mereka bahwa pemberi informasi (mu'allim) itu perlu bersifat ma'shum, tetapi hanya terbatas pada tingkat Nabi; sesudah Nabi orang tidak memerlukan imam yang mashum lagi, sebab Tuhan melalui Kitab Suci telah memberi kepada manusia ukuran (mîzan) dan alat untuk mengetahui kebenaran..$^{32}$ Kesimpulannya tentang bathiniyah ialah bahwa sistem pemahaman ini tidak memenuhi harapannya karena bathiniyah mengesampingkan daya manusia untuk menemukan kebenaran. Di sini taqlid menjadi hal yang sangat penting, sedangkan taqlid membawa keragaman dan pertentangan.

Pada ilmu kalam, al-Ghazâlî melihat kemandulan metodologi, kalau yang hendak dicari adalah hakikat-hakikat, sebab, ilmu ini tidak dipersiapkan untuk itu. Pada filsafat ia melihat ketidaklengkapan metodologi menyebabkan inkoherensi, karena, filsafat hanya mengandalkan akal semata. Pada bathiniyah ia melihat kekeliruan, karena dengan konsep al-talim, peran pengalaman, pengamatan, dan akal manusia sebagai alat-alat menemukan sendiri kebenaran dengan kitab suci sebagai pedoman, diabaikan, sehingga pengetahuan tidak diperoleh manusia dengan sendirinya.

Dalam tasawuf, cara yang ditempuh untuk menemukan hakikat, menurut alGhazâlî, terdiri atas dua tahap, yaitu tahap ilmu dan tahap amal. Ilmu yang dimaksud dalam hal ini adalah pengetahuan tentang konsep-konsep dan langkah-langkah yang harus ditempuh di dalam tasawuf, seperti zuhd, faqr, tawakkul, mahabbah, ma'rifah, dan sebagainya. Selain itu, diharuskan pula mengetahui syari'at, ilmu-ilmu 'aqliyah dan keimanan yang kuat terhadap tiga dasar keimanan. ${ }^{33}$ Yang dimaksud dengan amal adalah mengalami secara langsung konsep-konsep dan langkah-langkah yang harus dilalui itu. Ilmu dan amal menjadi menyatu. Kelihatannya, ia menganggaap bahwa pada sistem-sistem pemahaman lainnya ada keterpisahan antara ilmu dan amal, khususnya pada falsafat dan ilmu kalam. Kesan ini terlihat pada pernyataannya bahwa para sufi adalah arbab al-ahwâl (orangorang yang memiliki pengalaman langsung), ${ }^{34}$ bukan ash hab al-aqwâl (orang-orang yang berbicara). Dalam tasawuf pencarian hakikat tidak akan tercapai dengan pengetahuan saja, tetapi selain itu, harus dengan pengalaman langsung.

${ }^{31}$ Ibid.

${ }^{32}$ Al-Ghazâlî, Al-Qishthas al-Mustaqîm (Kairo: Maktabah al-Jundi, 1970), h. 18.

${ }^{33}$ Al-Ghazâlî, Al-Munqidz min al-Dhalâl, h. 42.

${ }^{34}$ Ibid., h. 43. 
Ketika ia menguji tasawuf, ia pada dasarnya tidak mengalami kesulitan tentang validitas sumber pengetahuan yang digunakan tasawuf, sebab sebelumnya ia telah yakin adanya intuisi (al-dzauq) sebagai sumber pengetahuan di atas akal. Akhirnya melalui pengalaman tasawufnya secara langsung, ia menemukan apa yang dicarinya.

Dari uraian tentang kesangsian al-Ghazâlî ini kelihatan bahwa akal dan al-dzauq merupakan persoalan yang penting. Keduanya adalah merupakan daya-daya terpenting dalam diri manusia.

\section{Pemenuhan Diri}

Manusia, pada hakikatnya, mempunyai kecenderungan yang inheren pada dirinya untuk mencapai sesuatu yang secara moral diyakininya baik. Dengan ungkapan lain dikatakan bahwa manusia senantiasa berada dalam perjalanan eskatalogis menuju keutamaan moralitas. Moralitas, selanjutnya, dijadikan ukuran kesempurnaan manusia. Karena itu, moralitas adalah masalah paling sentral dalam semua agama.

Moralitas tergolong kategori nilai. ${ }^{35}$ Agama-agama pada umumnya mengakui adanya nilai-nilai yang bersifat mutlak dan objektif, terutama dalam hal moralitas. Sebab, semua agama mengakui bahwa manusia dengan segala kemampuannya tidak dapat memenuhi kebutuhan-kebutuhannya dalam hal moralitas. ${ }^{36}$ Ketidakmampuan inilah yang menjadi dasar pikiran perlunya petunjuk dari Tuhan melalui rasul-rasul dan kitab-kitab suci.

Pemenuhan diri yang dimaksud di sini adalah upaya penyempurnaan diri sesuai dengan tuntutan moralitas itu. Dalam sejarah pemikiran Islam, konsep pemenuhan diri ini lebih jelas kelihatan di kalangan filsuf dan sufi daripada di lingkungan mutakallimun dan fukaha. Sebab mutakallimun dan fukaha tidak berorientasi kepada hakikat manusia (ontologi), sedangkan hakikat manusia merupakan persoalan yang sangat mendasar dalam moralitas. Ada kaitan yang konsisten antara hakikat manusia dan tujuan hidupnya.

Menurut al-Ghazâlî, manusia terdiri atas dua substansi yang berbeda, yaitu tubuh yang bersifat materi dan jiwa yang bersifat immateri (al-nafs). Hakikat manusia adalah al-nafs. ${ }^{37}$ Sebab, substansi inilah yang membedakannya dari seluruh yang ada ${ }^{38}$.

Manusia, sebenarnya mempunyai tiga tingkatan al-nafs, yaitu al-nafs al-nabatiyat (jiwa vegetatif), al-nafs al-hayawaniyat (jiwa sensitif) dan al-nafs al-insâniyat atau disebutnya

${ }^{35}$ James Hasting (ed.), Encyclopaedia of Religion and Ethics, vol. V (New York: Charles Scribner's Sons, t.t.), h. 584.

${ }^{36}$ Muhammad Abul Quasem, The Recitation and Interpretation of the Qur'an (London: Kegan Paul International, 1982), h. 9.

${ }^{37}$ Al-Ghazâlî, Ma'arij al-Quds fì Madârij Ma'rifat al-Nafs (Kairo: al-Jundi, 1968), h. 19, 24.

${ }^{38}$ Al-Ghazâlî, Mîzân al-'Amal (Kairo: Dâr al-Ma'arîf, 1961), h. 209-210. Hakikat pada umumnya diartikan sebagai sesuatu yang menyebabkan sesuatu, menjadi dirinya sendiri. Lihat Murad Wahbah, et. al., al-Mu'jam al-Falsafi (Kairo: al-Tsaqafat al-Jadîdah, 1971), h. 84, 201. 
juga dengan al-nafs al-nathiqat (jiwa rasional). Yang membedakan manusia dari segala yang ada adalah al-nafs al-nathiqat. ${ }^{39}$

Al-nafs al-nathiqat mempunyai dua sisi. Sisi yang berorientasi ke badan dan berfungsi sebagai pengatur badan disebutnya al-'aql al-'amali (akal praktis) dan sisi yang berorientasi ke atas ${ }^{40}$ yang berfungsi sebagai penyempurna substansinya sendiri dinamakannya al'aql al-ílmi (akal teoritis). Al-nafs selain mempunyai fungsi intelektual (nathiqah), juga mempunyai fungsi intuitif (al-dzauq) ${ }^{41}$

Al-Nafs sebagai hakikat manusia mempunyai sifat-sifat dasar yang berbeda dengan tubuh. Al-nafs tidak berada di dalam kontinum ruang dan waktu, bersifat immaterial, berada dalam kekekalan dan mempunyai kemampuan menangkap hal-hal yang abstrak. Sedangkan tubuh berada dalam kontinum ruang dan waktu, bersifat materi dan tidak mempunyai daya apapun. Karena itu, al-Ghazâlî menyatakan bahwa al-nafs adalah prinsip penggerak bagi tubuh. ${ }^{42}$ Gerak di sini tidak hanya berarti gerak fisik, tetapi bermakna aktivitas, termasuk di dalamnya aktivitas mengetahui. Pengetahuan manusia terhadap objek-objek material diperoleh karena al-nafs. Tanpa al-nafs, tubuh manusia tidak ada bedanya dengan benda-benda mati (al-jamad). ${ }^{43}$ Perbedaan sifat-sifat dasar antara alnafs dan tubuh terjadi karena keduanya berasal dari dunia yang berbeda; al-nafs berasal dari 'alam al-amr (disebutnya juga 'alam al-'aqli, 'alam al-ala, 'alam al-malakut), dan tubuh berasal dari 'alam al-khalq (disebutnya juga 'alam al-hiss, 'alam al-sufla, 'alam al-mulk). ${ }^{44}$

Pandangan tentang adanya dua dunia yang berbeda naturnya (thabi'at) sekaligus menunjukkan perbedaan dalam kualitasnya. 'Alam al-amr lebih tinggi tingkatnya daripada 'alam al-khalq. Ini berarti bahwa al-nafs lebih tinggi daripada tubuh. Selanjutnya, klasifikasi ini membawa al-Ghazâlî kepada kesimpulan yang menempatkan tubuh hanya bermakna secara instrumental. Yang bermakna instrinsik pada dirinya hanyalah al-nafs. Asumsi yang mendasari ini adalah bahwa kesempurnaan mutlak adalah Tuhan. Tuhan adalah wujud immaterial, tidak berada dalam kontinum ruang dan waktu dan berada dalam keabadian. Substansi yang paling dekat kepada kenyataan ini hanyalah al-nafs.

Menempatkan al-nafs sebagai hakikat manusia dan memandang daya-daya intelektual dan intuitif sebagai daya-dayanya yang terpenting menyebabkan al-Ghazâlî melihat kesempurnaan intelektualitas dan intuisi sebagai kriteria utama kesempurnaan manusia. Diri manusia dianggap penuh apabila intelektualitas dan intuisinya mencapai kesem-

${ }^{39}$ Ibid., h. 27.

${ }^{40}$ Al-Ghazâlî, Mîzân al-'Amal, h. 204-205.

${ }^{41}$ Al-Ghazâlî, Ihyya' 'Ulûm al-Dîn, Juz VIII (Beirut: Dâr al-Fikr, 1980), h. 14.

${ }^{42}$ Ibid., h. 291.

${ }^{43}$ Al-Ghazâlî, Mîzân al-'Amal, h. 209-210.

${ }^{44}$ Al-Ghazâlî, Misykat al-Anwâr (Kairo: Maktabat al-Jundi, 1970), h. 26; al-Ghazâlî, Ma'ârij alQuds, h. 23. 
purnaan. Pemenuhan diri, dengan demikian, adalah peningkatan fungsi intelektualitas dan intuitif sesuai dengan perannya masing-masing.

Peningkatan ini tidak hanya dilakukan dengan peningkatan kemampuan saja. Bersamaan dengan itu, pembersihan diri dari pengaruh-pengaruh negatif kehidupan material harus dihindari. Artinya, tuntutan-tuntutan hidup material harus diletakkan sebagai alat yang menunjang kesempurnaan diri.

Pembersihan diri yang pertama tentunya adalah dari pengaruh-pengaruh negatif kehidupan material, yang di dalam istilah tasawuf disebut al-zuhd. Tetapi, pembersihan diri yang sesungguhnya adalah meninggalkan segala bentuk ma'shiat. Ma'shiat sering berasal dari pengaruh-pengaruh kehidupan material. Sebab, segala kegiatan ma'shiat bermula dari pemenuhan kebutuhan-kebutuhan badani. Pemenuhan kebutuhan badani harus dilakukan dengan menempatkannya sebagai instrumen bagi pemenuhan kebutuhan al-nafs dan disesuaikan dengan ketentuan-ketentuan syara' ${ }^{45}$

Pembersihan diri ini disebutnya juga dengan al-takhliyat, yaitu mengosongkan diri dari sifat-sifat tercela. Pengosongan ini sekaligus berlanjut dengan pengisian kembali dengan sifat-sifat terpuji yang disebutnya dengan al-tahliyat. Al-Takhliyat dan al-tahlityat dilakukan dengan latihan yang panjang. Apabila dengan latihan ini al-nafs mencapai tingkat tertentu di mana keinginan untuk selalu mengarah kepada Tuhan mencapai kestabilannya, al-nafs disebutnya al-nafs al-muthmainnat. ${ }^{46} \mathrm{Al}$-nafs yang selalu dalam perjuangan menentukan orientasi kepada Tuhan atau kepada tuntutan-tuntutan badani disebutnya al-nafs allawwamat. Al-nafs yang lebih rendah adalah selalu berorientasi kepada tuntutan-tuntutan badani. ${ }^{47}$ Dengan latihan yang terus-menerus, al-nafs al-muthmainnat, setelah melalui fase al-takhliyat dan al-tahliyat, mencapai tingkat al-tajalli. Pada tingkat ini pengetahuanpengetahuan abstrak dan informasi-informasi tentang dunia gaib terbuka kepada al-nafs. Manusia pada tingkatan ini telah mencapai kesempurnaanya. ${ }^{48}$

Pembersihan diri ini merupakan penanaman kesadaran moral. Latihan yang panjang itu akhirnya akan melahirkan kesadaran moral yang sangat dalam. Al-Ghazâlî senantiasa menekankan keharusan mempedomani syara' dalam kegiatan pembersihan diri. Sebab, menurutnya, manusia dengan sendirinya tidak mampu mengetahui baik dan buruk secara praktis. Akal manusia hanya mampu mengetahui baik dan buruk secara universal (kulli). ${ }^{49}$

Pemenuhan diri ini diperlukan karena merupakan tuntutan hakikat manusia. Hakikat

${ }^{45}$ Al-Ghazâlî, Macârij al-Quds, h. 99.

46Ibid., h. 20; al-Ghazâlî, Ihya' 'Ulûm al-Dîn, Juz VIII (Beirut: Dâr al-Fikr, 1980), h. 7.

${ }^{47}$ Ibid.

${ }^{48}$ Pengertian konsep-konsep al-tahliyat, al-takhliyat, dan al-tajalli dapat dilihat pada al-Ghazâlî, Al-Imla' fì Isykalat al-Ihyyâ' (Beirut: Dâr al-Fikr, 1980), h. 9.

${ }^{49}$ Al-Ghazâlî, Ma'ârij al-Quds, h. 65. 
manusia mengandung kecenderungan secara fithri untuk tauhî̀d. ${ }^{50}$ Tauhî̀ adalah pengetahuan yang lebih sempurna tentang Tuhan.

Dari uraian di atas dapat diketahui bahwa pemenuhan diri menurut al-Ghazâlî mencakup penajaman daya-daya al-nafs, terutama fungsi intelektual dan intuitifnya, peningkatan kesadaran moral, dan ketaatan kepada ajaran-ajaran syara' Dengan demikian, al-Ghazâlî telah membuat satu kombinasi kreatif antara filsafat, tasawuf dan syari'at. Ketiganya ditempatkan sebagai unsur-unsur yang bersifat komplementer untuk membentuk satu integralitas dalam pribadi seorang Muslim yang sempurna.

\section{Modernisme dan Kritik Pascamodernisme}

Abad modern dimulai dengan revolusi ilmu pengetahuan. Revolusi ilmu pengetahuan ditandai dengan kemenangan Rasionalisme dan Empirisme dari dogmatisme agama di Barat. ${ }^{51}$ Perpaduan Rasionalisme dan Empirisme dalam satu paket epistemologi melahirkan apa yang disebut metode ilmiah. Dengan metode ilmiah, kebenaran pengetahuan hanya diukur dengan kebenaran koherensi dan kebenaran korespondensi. ${ }^{52}$ Pengetahuan diakui dari sudut ilmiah apabila secara logika bersifat koheren (runtut) dengan kebenaran sebelumnya dan didukung oleh fakta empiris (koresponden).

Kepercayaan yang sangat tinggi terhadap metode ilmiah yang demikian tampaknya membawa kesadaran yang kurang atau bahkan tidak apresiatif terhadap pengetahuan yang berada di luar lingkup pengujian metode ilmiah, termasuk pengetahuan dan nilainilai religius. ${ }^{53} \mathrm{Ilmu}$ betul-betul bersifat sekular sekular, dan manusia pun hanya diperhitungkan dari sudut biologis dan fisiologisnya. Ilmu-ilmu pengetahuan yang lahir dari penerapan metode ilmiah ini demikian pesatnya dan memberikan kepada manusia pengetahuan yang semakin tajam tentang alam semesta. Manusia semakin sempurna menaklukkan dan mengolah alam untuk tujuan memperoleh kemudahan dalam kehidupan. Hubungan ilmu pengetahuan dengan nilai-nilai, terutama yang berasal dari agama, pada tingkat yang ekstrim dianggap bersifat kontradiktif; sekurang-kurangnya ilmu pengetahuan terbebas dari nilai dalam arti menyeluruh. ${ }^{54}$ Secara singkat dapat disimpulkan bahwa kerangka berpikir keilmuan manusia modern berusaha melepaskan diri dari dimensi spiritual. Kesadaran manusia digiring ke arah yang sekular.

${ }^{50}$ Al-Ghazâlî, Mîzân al-'Amal, h. 335. h. ix.

${ }^{51}$ F. B. Burnham (ed.), Postmodern Theology (San Fransisco: Harper \& Row Publishers, 1989),

${ }^{52}$ Suriasumantri, Ilmu dalam Perspektif, h. 11-12.

${ }^{53}$ Lihat misalnya pernyataan Betrand Russel mengenai kehidupan sesudah mati, dalam Bertrand Russel, Religion and Science (London: Oxford University Press, t.t.), h. 142; T.G. Masaryk, Modern Man and Religion (Westport-Connecticut: Greenwood Press, Publishers, 1970), h. 55.

${ }^{54}$ Dari pandangan inilah muncul semboyan "ilmu untuk ilmu". 
Sebenarnya modernisme dengan segala cirinya adalah refleksi kritis terhadap kerangka berfikir dan kesadaran abad-abad pramodern yang bercorak otoritarianisme. ${ }^{55}$ Refleksi kritis ini muncul ketika kerangka berpikir dan kesadaran yang bercorak otoritarianisme dirasakan tidak lagi dapat menyelesaikan persoalan-persoalan yang dihadapi oleh ummat manusia. Demikian juga halnya dengan kerangka berpikir keilmuan dan kesadaran modernisme, ketika dirasakan kelemahan-kelemahannya dan dampak-dampak negatif yang dibawanya kembali muncul kritik-kritik terhadapnya.

Secara umum, yang dirasakan sebagai kelemahan pola berpikir keilmuan modern adalah kepercayaannya yang berlebihan terhadap akal dengan mengenyampingkan dimensi spiritual dan nilai-nilai keagamaan. ${ }^{56}$ Pertimbangan nilai dalam rangka pengembangan dan penggunaan ilmu pengetahuan dan teknologi tidak mendapat tempat yang sewajarnya. Akibatnya, ilmu pengetahuan dan teknologi dalam banyak hal tidak menyelesaikan persoalan kehidupan, bahkan membawa persoalan baru yang lebih serius. Dalam hal kesadaran manusia modern, yang dirasakan kelemahanya adalah rapuhnya pegangan moral dan hilangnya orientasi hidup yang bermakna. Tujuan hidup terbatas pada pencapaian sasaransasaran yang bersifat material dan duniawi. Keadaan ini membawa manusia kepada keterasingan, frustasi, dan kehampaan eksistensial. ${ }^{57}$

Metode ilmiah yang sama sekali bebas nilai dan kesadaran manusia yang terlepas dari dimensi spiritual terbukti tidak membawa kebahagian dalam kehidupan manusia.

Bersamaan dengan kritik-kritik itu timbul pula revisi dalam bentuk merelatifkan keabsolutan yang selama ini dinisbahkan kepada metode ilmiah, sekaligus berupaya membuka jalan bagi masuknya nilai-nilai ketuhanan dan dimensi spiritual ke dalam dasar ontologi dan dasar aksiologi keilmuan. Bahkan ada yang melihat bahwa nilai-nilai dapat masuk ke dalam proses metodologi keilmuan. Metode ilmiah tidak dapat lagi dipertahankan bersifat netral dalam arti yang mutlak.

Dalam hal kesadaran manusia secara praktis timbul gejala pencarian makna hidup dan upaya pemenuhan diri pada kepercayaan-kepercayaan yang sarat dengan spiritualitas. Organized religion tidak selamanya dapat memenuhi harapan. Sebab itu, bermunculan kecenderungan untuk kembali kepada orisinalitas (fundamentalis), kharisma yang menentukan (cults), dan fenomena-fenomena yang luar biasa (magic).

Keberagamaan manusia pascamodern cenderung bersifat pencarian pribadi. ${ }^{58}$ Sudah tentu, ini selamanya tidak membawa hasil yang positif. Sejumlah kelompok keagamaan sempalan menunjukkan gejala-gejala yang negatif, bahkan bukan tidak mungkin dalam

${ }^{55}$ Otoritarianisme selanjutnya dapat dilihat pada G.T.W. Patrick, Introduction to Philosophy (London: George Allen and Unwin Ltd., t.t.), h. 327-329.

${ }^{56}$ Masaryk, Modern Man and Religion.

${ }^{57}$ Bergin, "Psikoterapi dan Nilai-Nilai Religius," h. 5.

${ }^{58} \mathrm{Ahmed}$, Postmodernism and Islam, h. 10. 
hal seperti ini terjadi manipulasi keadaan dengan maksud mengambil keuntungan dari kehausan manusia-manusia yang kehilangan pegangan dan orientasi hidup itu.

Berbeda dengan kritik modernisme terhadap kerangka berpikir keilmuan dan kesadaran pramodern, kritik pascamodernisme terhadap kerangka berpikir keilmuan dan kesadaran manusia modern lebih merupakan revisi penyempurnaan ketimbang penghancuran. Kritik pascamodernisme tidak menghilangkan rasionalitas dan tidak mengalihkan perhatian manusia dari fenomena material ke dunia spiritual, tetapi melengkapi rasionalitas dengan dasar-dasar filosofi yang memuat pandangan dunia ${ }^{59}$ dan moralitas keagamaan.

\section{Penutup}

Dari uraian tentang epistemologi al-Ghazâlî di atas, tampak jelas bahwa pengamatan dan akal tidak dapat diandalkan sebagai dasar kebenaran pengetahuan secara mutlak. Ada daya lain di dalam diri manusia untuk menangkap pengetahuan tertentu yang lebih tinggi dengan sifat dan ukuran-ukurannya sendiri, yaitu intuisi (al-dzauq). Al-Ghazâlî tidak mengabaikan pengamatan dan akal, tetapi meletakkannya sesuai dengan watak masingmasing secara proporsional. Apabila dilihat dalam konteks modernisme dan pasca modernisme, signifikansi epistemologi al-Ghazâlî adalah pada penempatan ketiga daya itu secara proporsional sesuai dengan wataknya masing-masing, dan hubungan antara satu dan lainnya yang bersifat komplemeter. Ini membawa konsekuensi keharusan adanya landasan teologis dan moral bagi ilmu pengetahuan.

Dari segi kesadaran manusia, dengan mudah dapat dilihat signifikansi pemikiran alGhazâlî. Manusia modern membutuhkan pegangan moral dan makna hidup. Al-Ghazâlî menawarkannya dalam bentuk pemenuhan diri yang diuraikan di atas, yaitu dengan meningkatkan fungsi daya-daya yang ada pada diri manusia dan mendekatkan diri kepada Tuhan.

Dari pembahasan tentang epistemologi al-Ghazâlî dan pandangannya tentang orientasi hidup dihubungkan dengan konteks zamannya, kedua aspek pemikiran itu mempunyai signifikansi dengan kebutuhan perkembangan epistemologi dan kesadaran pasca-Modernisme.

\section{Pustaka Acuan}

'Abd al-Rahman Badâwî. Muallafat Al-Ghazâlî. Damaskus: al-Majlis al-A'la li Ri'ayat alFunûn, 1961.

Ahmed, Akbar S. Postmodernism and Islam. London-New York: Routledge, 1992.

${ }^{59}$ Huston Smith, Postmodernism and World's Religion (Makalah, disampaikan pada Inaugural Symposium: Islam and the Challenge of Modernity, ISTAC Kuala Lumpur, 1-5 Agustus 1984, h. 9. 
Bastaman, Hanna Djumhana. "Dimensi 'Spiritualitas' dalam Teori Psikologi,” dalam Ulumul Quran, Nomor 4, Vol. V, 1994.

Burnham, F. B. (ed.). Postmodern Theology. San Fransisco: Harper \& Row Publishers, 1989.

Cassirer, Ernst. Manusia dan Kebudayaan, terjemahan Alois A. Nugroho. Jakarta: Gramedia, 1987.

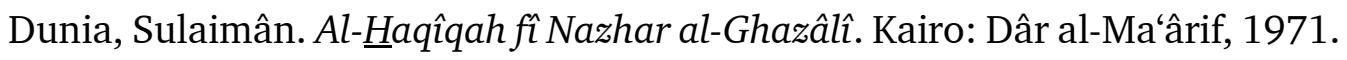

Al-Ghazâlî. Al-Imla'fí Isykalat al-Ihyyâ'. Beirut: Dâr al-Fikr, 1980.

Al-Ghazâlî. Al-Iqtishâd fí al-I'tiqâd. Kairo: Muhammad 'Alî Shubaih, 1962.

Al-Ghazâlî. Al-Munqidz min al-Dhalâl. Kairo: Silsilah al-Tsaqafat al-Islâmiyah, 1961.

Al-Ghazâlî. Al-Qishthas al-Mustaqîm. Kairo: Maktabah al-Jundi, 1970.

Al-Ghazâlî. Inhyâ' 'Ulûm al-Dîn, vol. VIII. Beirut: Dâr al-Fikr, 1980.

Al-Ghazâlî. Ma'ârij al-Quds fî Madârij Ma'rifat al-Nafs. Kairo: al-Jundi, 1968.

Al-Ghazâlî. Mi’yar al-'Tlm. Kairo: Dâr al-Ma'ârif, 1960.

Al-Ghazâlî. Misykat al-Anwâr. Kairo: Maktabat al-Jundi, 1970.

Al-Ghazâlî. Mîzân al-'Amal. Kairo: Dâr al-Ma'arif, 1961

Hasting, James, (ed.). Encyclopaedia of Religion and Ethics, Vol. V. New York: Charles Scribner's Sons, t.t.

Madjid, Nurcholish. Khazanah Intelektual Islam. Jakarta: Bulan Bintang, 1984.

Masaryk, T.G. Modern Man and Religion. Westport-Connecticut: Greenwood Press, Publishers, 1970.

Patrick, G. T. W. Introduction to Philosophy. London: George Allen and Unwin Ltd., t.t.

Quasem, Muhammad Abul. The Recitation and Interpretation of the Qur'an. London: Kegan Paul International, 1982.

Russel, Bertrand. Religion and Science. London: Oxford University Press, t.t.

Smith, Huston. Postmodernism and World's Religion. Makalah, disampaikan pada Inaugural Symposium: Islam and the Challenge of Modernity, ISTAC Kuala Lumpur, 1-5 Agustus 1984.

Al-Subkî. Thabaqat al-Syafi'iyah al-Kubrâ, Juz IV. Mesir: Mushthafa al-Bâbî al-Halabi, t.t. Suriasumantri, Jujun S. Ilmu Dalam Perspektif. Jakarta: Gramedia, 1983.

'Utsman, 'Abd al-Karîm. Sîrah al-Ghazâlî. Damaskus: Dâr al-Fikr, t.t.

Wahbah, Murad, et al. Al-Mu’jam al-Falsafi. Kairo: al-Tsaqafat al-Jadidah, 1971.

Watt, W. Montgomery. The Faith and Practice of al-Ghazâlî. London: George Allen and Unwin Ltd., 1953. 